\title{
The Pattern of Disaster Communication and Media to Improve Community Alertness in North Aceh Regency
}

\section{Pola Komunikasi Bencana dan Media dalam Meningkatkan Kesiapsiagaan Masyarakat di Kabupaten Aceh Utara}

\author{
Fauzi $^{1)}$, Marhamah ${ }^{2)}$ \\ ${ }^{1}$ Universitas Islam Kebangsaan Indonesia (UNIKI) Bireuen \\ ${ }^{2}$ Institut Agama Islam Negeri Lhokseumawe \\ ${ }^{1}$ Jalan Medan - Banda, Aceh Blang Bladeh, Bireuen \\ ${ }^{2}$ Jalan Medan - Banda Aceh, Buket Rata, Kota Lhokseumawe \\ fauzikalia2017@gmail.com ${ }^{1)}$, marhamahrusdy@gmail.com ${ }^{2)}$ \\ Diterima : 1 Mei 2020 || Revisi : 22 Agustus 2020 || Disetujui: 9 September 2020
}

\begin{abstract}
This study aims to analyze the forms of communication carried out and the media used by the North Aceh District Disaster Management Agency in improving community alertness. This research uses descriptive research type, and qualitative research approaches. Research data obtained through interviews, observations, and documentation studies. Research informants, namely the Local Government, the Head of the North Aceh District Disaster Management Agency, the District Head of Langkahan, the Head of North Aceh SAR, the Head of RRI Lhokseumawe. The results showed that the communication carried out by the North Aceh District Disaster Management Agency was interpersonal communication and mass communication through socialization and simulation about disasters. While the communication media used, namely the mass media both print media and radio media to inform disaster management policies. It also used traditional media as local wisdom namely kentongan. Kentongan media are considered effective when communication tools that use technology do not function.
\end{abstract}

Keywords: Communication, Mitigation, Disaster, alertness, North Aceh Regional Disaster Management Agency.

\begin{abstract}
Abstrak - Penelitian ini bertujuan untuk menganalisis bentuk komunikasi yang dilakukan dan media yang digunakan oleh Badan Penanggulangan Bencana Kabupaten Aceh Utara dalam meningkatkan kewaspadaan masyarakat. Penelitian ini menggunakan jenis penelitian deskriptif, dan pendekatan penelitian kualitatif. Data penelitian diperoleh melalui wawancara, observasi dan studi dokumentasi. Informan penelitian yaitu Pemerintah Daerah, Kepala Badan Penanggulangan Bencana Kabupaten Aceh Utara, Camat Langkahan, Kepala SAR Aceh Utara, Kepala RRI Lhokseumawe. Hasil penelitian menunjukkan bahwa komunikasi yang dilakukan oleh Badan Penanggulangan Bencana Kabupaten Aceh Utara adalah komunikasi interpersonal dan komunikasi massa melalui sosialisasi dan simulasi tentang kebencanaan. Sedangkan media komunikasi yang digunakan yaitu media massa baik media cetak maupun media radio untuk menginformasikan kebijakan penanggulangan bencana. Lembaga ini juga memanfaatkan media tradisional sebagai kearifan lokal yaitu kentongan. Media kentongan dinilai efektif apabila alat komunikasi yang menggunakan teknologi tidak berfungsi.
\end{abstract}

Kata Kunci: Komunikasi, Mitigasi, Bencana, Kesiapsiagaan, Badan Penanggulangan Bencana Daerah Aceh Utara.

\section{INTRODUCTION}

Indonesia is one of the countries prone to natural disasters, such as volcanic eruptions, earthquakes, and tsunamis. Located at the confluence of three tectonic plates of the world makes Indonesia an area through a belt of fire or ring of fire (Suhardjo, 2011). Earthquake is one of the natural disasters which is still unpredictable when it will happen; even the most modern device ever invented, but still, it cannot predict when the seismic energy releases its gigantic power (Emosda \& Fadzlul, 2014). One of the natural disasters is the one which devastated Aceh Province. Aceh
Province is a region which is frequently hit by earthquake, tsunami, volcanoes, flash flood, and landslides. The earthquake and tsunami that occurred in Aceh on December 26, 2004, demolished Aceh and the surrounding and killed around 170 thousand people (Febriana et al., 2015). There were still other natural disasters in Aceh which claimed a huge loss of lives and materials. North Aceh Regency is one of the areas in Aceh tending to be highly affected by natural disasters. Topographically, North Aceh Regency is bordered with the sea to the north and Malacca Strait and skirt of the mountains to the south. Given the 
topographical character and the pattern of the river flow, North Aceh becomes the flood and heavy rainprone area. The floodwater usually overflows the river bank, especially in the eastern regions of (RPI2JM, Cipta Karya in North Aceh Regency, 2016-2020). The occurrences of a disaster in North Aceh which claimed a massive loss of lives and materials, provides the lesson learned on the importance of community awareness of the disasters.

The establishment of the Regional Disaster Management Agency (BPBD) by local government is a need to operate the disaster management to mitigate the risk of the disaster. This agency is functioning as the field coordinator in charge of mitigating the disaster, namely in emergencies to carry out rehabilitation in the aftermath of a disaster and also to improve community preparedness for disaster response. According to (Carter, 2008), preparedness is a quick and effective response from the government, organizations, communities, communicants, and individuals to disaster situations. Included in disaster response actions, namely planning, control, maintenance to training personnel. Alertness means efforts to prepare the community in anticipating possible disasters to reduce the loss of life, property, and in the future (Sutton \& Tierney, 2006). Disaster risk reduction priorities are necessarily implemented in the education sector to create a disaster-resilient generation. To increase the understanding of the risk of the disaster can be carried out through socialization and educational activities; all of this effort is to reduce the risk of a disaster in an area (Pahleviannur, 2019).

Acquired knowledge should be effective, not just to understand the case but also to apply it in daily life (Seneviratne, 2010). According to the International Federation of Red Cross and Red Crescent Societies, disaster alertness refers to actions taken to prepare and reduce the impact of disasters. The alertness efforts undertaken at the time the disaster to be identified, among others; (a) activating disaster alert posts with all supporting elements, (b) training on standby/simulation/rehearsal/technical for the personnel involved such as SAR, health, and social workers, (c) providing support staff, (d) preparing logistics, (e) preparing a fast integrated communication and information system for disaster workers, (f) preparing and installing an early warning system, (g) planning, and (h) mobilizing all resources (UNESCO LIPI, 2008). Therefore, to guarantee disaster preparedness requires preparation including support of resources, logistics, early warning facilities, and a fast integrated communication and information system. Meanwhile, for the effectiveness of community preparation for disasters, it can be seen starting from the emergency response activities to the post-disaster rehabilitation activities

Disaster management is carried out by using a communication approach to shape community alertness. This activity is carried out through information dissemination on disasters. Disaster information conveyed by BPBD can create an understanding for the community of the importance of knowledge about disasters. Explains that communication is at the core of the success of disaster mitigation, alertness, response, and providing postdisaster rehabilitation (Haddow \& Haddow, 2014). Communication always involves humans and interactions, so that communication can be said as a social process (West \& Turner, 2017). So, communication is the process of delivering messages which always involve communicators and communicants, and those involved in communication play an important role. Then as a process, communication is carried out continuously in an ongoing and endless manner. Communication also takes place in a situational context (situational context), communicators must pay attention to the situation factors when the communication takes place. Communication is informative, which is conveying information. Communication is also persuasive aiming to change the communicant's understanding so that it follows what is desired by the communicator. Besides, communication is always dynamic, changing, and complex.

Essentially, a large part of personal communication is formed from the results of social interaction with each other. Etymologically, the term communication comes from the word common which means the same meaning (Liliweri, 2015). Communication is the occurrence of similarities between the communicator and the communicant of a message (Effendy, 2017). In the process of communication, the similarity of meaning becomes important to form the same understanding. Therefore, the concept of reducing uncertainty is an important aspect of communication (Littlejohn \& Foss, 2014). The formation of communication due to the need to reduce uncertainty, so that interaction between individuals or groups is effective. Some previous studies that are relevant to this study, research with the title: "Communication in 
Disaster Management". The results of the study describe that communication in a disaster is not only needed in a state of disaster emergency but is also it is important during pre-disaster. In a state of disaster emergency, communication is needed as a function of management and coordination between the government, victims, the community, volunteers, and the mass media. During the rehabilitation or postdisaster period, communication is also important to restore the affected community to normal living conditions, conducting counseling, socio-economic empowerment, and restoring the social life of the community (Rudianto, 2015).

Community preparedness in facing disasters is determined from the information it gets through the mass media. In disaster-prone areas, the media plays a strategic role in educating the public. The mass media must always convey information about disasters that can be used as a guide for the community. The mass media plays a very important role in disaster mitigation through the dissemination of information both before a disaster, during a disaster, and after a disaster. Before the disaster happened, the mass media monitored warnings about the emergence of symptoms of a disaster. Meanwhile, when a disaster occurs, the mass media increases the intensity of information about the disaster to persuade disaster victims. And after a disaster occurs, the mass media plays a role in monitoring the infrastructure in the affected areas (Rahayu et al., 2014). The role of the media in disseminating information about disasters is inevitable. The media plays an important role as carriers of information and as part of a disaster information management operation. This role is not only related to reporting tasks but also in humanitarian activities (Prajarto, 2008). Media is a means used to convey information from a person to the public. Media is a tool used by communicators to convey messages to audiences (Cangara, 2015). In communicating, the dominant media is the human senses which are then processed by the mind so that it can determine attitudes and manifest in the form of action. Based on this definition, it can be understood that the media act as an intermediary in delivering information so that communication effectiveness can be achieved.

Other studies have also examined disaster-related communication, (Lestari et al., 2016), the results of the study explained that environmental communication in the disaster area is inseparable from the level of knowledge and attitudes about various matters relating to environmental disasters, both physical and environmental disasters of the community and government. On the other hand, environmental communication is a vehicle to provide knowledge and understanding to the public about good environmental planning to function effectively and provide maximum benefits for the creation of community behavior that is conducive to the environment. A disaster is a natural event. The event can be human actions that occur suddenly, causing a large impact on society, which must be responded immediately with extraordinary actions (Carter, 2008). In-Law Article 1 No. 24 of 2007 states that disasters are extraordinary events due to natural factors, non-natural factors, or human factors that cause loss of life, loss of property, environmental damage, and even psychological impacts. Disasters are divided into, natural disasters consisting of floods, earthquakes, tsunami, storm, and others, technological disasters such as nuclear explosions, and complex emergencies consisting of conflict, war and others (Bakornas PB, 2007). Disaster management (disaster management) is an activity or series of activities that are comprehensive, integrated, and continuous which constitutes a cycle of activities including 1). before a disaster occurs namely prevention, mitigation, preparedness, and vigilance; 2). at the time of the disaster starting from giving early warning, evacuation, rescue, and looking for victims; and 3). after the disaster, it requires rehabilitation, healing, sponsorship, and reconstruction of human settlements (Shaw et al., 2009).

Meanwhile, disaster management components, namely: 1. Mitigation, reduction or elimination of the components of hazard risk; 2) alertness, preparation of people who are at risk of being affected by a disaster; 3) response, actions to minimize the impact of disasters; and 4) recovery, repairing the damage again so that it does not cause chaos in the future (Coppola \& Maloney, 2009). This study proposes the use of communication patterns in the delivery of disaster information and various media, namely mass media, online media, social media, and traditional media. The importance of communication patterns in disaster management to synergize disaster information from the BPBD to the community as well as to other parties concerned. Because the communication pattern is the plan and steps of the BPBD that are conveyed to related parties, volunteers, or task forces are more alerts in disaster management. Likewise with the use of mass media and social media which have an important role 
to communicate disaster information objectively and accurately. Besides, the use of media can facilitate mapping and finding out the location of disasters so that disaster management is more effective. The benefits of this research are that the North Aceh BPBD uses effective communication patterns and appropriate media following its communicants in delivering accurate information so that it gives peace to the community and it is believed that the government can respond to disasters appropriately. The pattern of effective communication is important to avoid the mistakes and uncertainties of information that can worsen the situation. It is also an effort to minimize the occurrence of casualties or material losses.

\section{RESEARCH METHOD}

This study uses descriptive research and a qualitative approach because this study was conducted to make a description, picture or painting systematically, factually, and accurately about the facts, traits, and relationships between the phenomena investigated (Nasution, 2012). In this case, the researcher intends to describe objectively and in detail about the communication patterns and media used by the North Aceh BPBD in increasing community preparedness.

The method used to collect data, namely literature study by studying documents or literature related to communication patterns. Then, conduct in-depth interviews in a structured manner and make observations related to disaster management activities. This research was conducted in North Aceh Regency with 7 informants, namely the Head of the North Aceh BPBD, North Aceh Regency Government, Langkahan District Head, North Aceh SAR Team, Chairperson of the Buket Linteung Village Disaster Risk Reduction Forum, Head of RRI Lhokseumawe. To maintain the validity of the data, a triangulation technique is used to compare the level of accuracy of information or data obtained through interviews with data obtained through observation and documentation.

Data were analyzed starting from before the field by analyzing the results of the preliminary study. Then the analysis after the field is done at the time of data collection takes place and after data collection is complete. Data analysis was carried out in three stages, namely: the stage of data reduction by summarizing, selecting the main points, focusing on the important matters; the stage of presenting data by compiling a set of data narratively so that it will be easily understood; and the verification stage, which is concluding.

\section{RESULT AND DISCUSSION \\ Communication Pattern to Improve Community Alertness}

Based on the results of research that has been done, the form of communication carried out by the North Aceh Regency Disaster Management Agency in improving disaster preparedness for people in disasterprone areas is interpersonal communication. Interpersonal communication is a face-to-face interaction between the message giver to the recipient of the message. North Aceh BPBD interpersonal communication is carried out through socialization to provide an understanding of disaster actions that the community must take in dealing with disasters (interview with Amir Hamzah, Head of North Aceh BPBD). The socialization that was carried out was an effort by the North Aceh BPBD to improve the community's ability to face disasters.

Dissemination is also an effort to educate the public on disasters by providing material on understanding disasters, the impacts caused by disasters, and efforts to mitigate these disasters. Besides that in disaster mitigation education, public awareness about disaster events is needed. Therefore, through socialization, it is expected to know how the sensitivity of the community to disaster. The level of community sensitivity is an indicator of the level of awareness of disaster risk as well as the response and mitigation that has become his knowledge and perspective. Disaster mitigation socialization must be carried out continuously and continue to be entrenched in the community because community awareness and preparedness for disasters are one of the non-structural disaster mitigation that must be strengthened. It would be even more effective if the regular socialization was also accompanied by a simulation (interview with Mukhtar, Chair of the Buket Linteung Village Disaster Risk Reduction Forum, Langkahan District).

Dissemination on disaster mitigation is also the dissemination of accurate information about disasterprone areas, as well as actions that must be taken by the community when disaster strikes. Dissemination about disaster can reduce the risk of disasters, both loss of life and material loss. The socialization carried out by the North Aceh BPBD included how to access information with existing technological facilities. The socialization was carried out in collaboration with the local 
government and BPBD (interview with Hasbullah, North Aceh SAR Head). Dissemination on disaster mitigation can connect various parties between the community, government, and BPBD. That is, the socialization becomes the process of exchanging information to form a better interaction between various parties. Communication of the North Aceh BPBD in improving community alertness in facing disasters is also done by mapping disaster-prone areas. This mapping is based on the level of risk posed, namely high, medium, and low risk. So, through this mapping appropriate measures can be arranged. Information about each level of disaster risk and appropriate actions was conveyed through socialization in all villages in cooperation with village officials, PMI, and SAR (interview with Amir Hamzah, Head of North Aceh BPBD). Inner community mechanism faces the incident (coping mechanism) formed and born from experience, knowledge, understanding, and meaning against every event, phenomenon, hope, and the problems that occurred around him (Maarif, 2012). The mechanism is passed through a process generation to generation and socialization its implementation depends on the content the quality of understanding and its implications in Their life. Posyandu roles are as a knowledge transfer agent potential health agents as well as the transfer of disaster knowledge in the scope of the village community

The North Aceh BPBD acts as the coordinator in implementing planned, integrated, and comprehensive disaster management activities. Therefore, BPBD cooperates with various elements. At the stage of disaster prevention and alertness, the North Aceh BPBD collaborates with the Regional Government Work Unit related to disaster management. Likewise, when a disaster occurs, the North Aceh BPBD cooperates with the Social Service in terms of logistical assistance and with the Health Service in terms of providing medical assistance. In this case, the Health Service in providing health services also cooperates with TAGANA (Disaster Alertness Team) and PMI (Indonesian Red Cross) to establish a health post for victims whose homes cannot be occupied anymore due to disaster. Communication systems that need to be carried out in disaster management are before, during, and after a disaster or in the recovery phase. This process is carried out by involving various parties such as the government as the center for coordination and information, the private sector, NGOs, or similar organizations to support the government, then the media as the party that assists the government in regulating the flow of information and the public as the party implementing the system created (Arisandi \& Umam, 2019), Based on the data findings seen from the form of organizational communication, the North Aceh BPBD uses a star communication pattern or also called the communication pattern of all channels. Star communication patterns are interpreted as a description of the form or way of communicator in conveying messages both directly and through the media in the context of relationships and interactions that take place in society (Widjaja. H.A.W, 2010).

In other words, each member can communicate with all other group members. In this case, the North Aceh BPBD can communicate directly with the community through direct socialization activities and various media without being limited to the bureaucratic structure. Besides, the North Aceh BPBD uses chain communication patterns, namely communication patterns with upward and downward communication systems. This model adheres to direct line communication (command), both up and down without an intersection. From the data findings, the North Aceh BPBD is in the position of leader, which is the coordinator in delivering disaster management information and in collaboration with various elements. The mapping of disaster-prone areas is important because the actions are taken in handling these disasters differ. Each disaster risk will vary in each village. So, the handling must be following the level of vulnerability. Based on this risk analysis, a recommendation will be issued (interview with Mukhtar, Chair of the Buket Linteung Village Disaster Risk Reduction Forum, Langkahan District). This is important to do in anticipation of a disaster. Moreover, almost every year in North Aceh Regency there are always disasters, such as in Gampong Buket Linteung, Langkahan District as one of the areas prone to flooding and landslides. Every rainy season the area always gets a flood of submissions from Bener Meriah Regency there was even a very severe flood, namely water reaching the shoulders of adults (interview with Kausar, Langkahan Sub-District).

In addition to providing socialization to the community, the North Aceh BPBD also conducted simulations to provide self-refraction while simultaneously testing community preparedness regularly. 


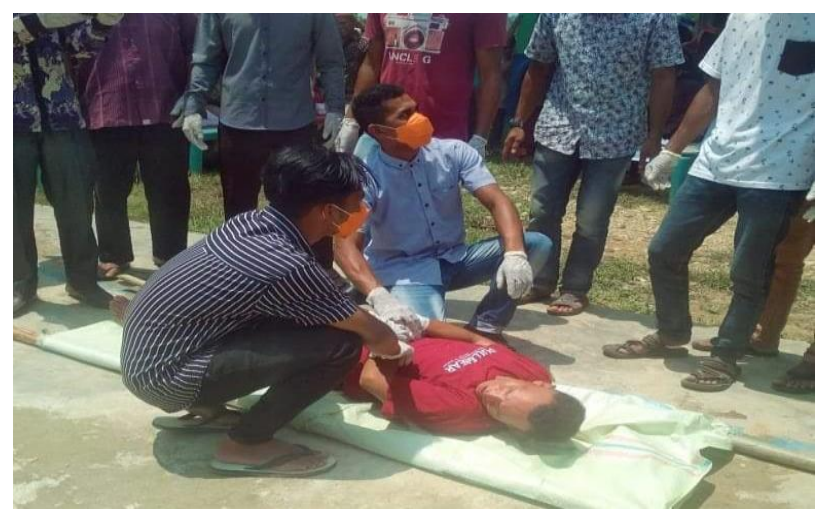

Figure 1 Disaster Mitigation Simulation

The simulation covers the method of evacuation. The implementation of the simulation begins with a briefing, then exercises to identify the evacuation route regularly after and important emergency numbers, to the gathering point. The simulations are an effort to provide skills in helping themselves and others as disaster risk reduction efforts (interview with Muhtar, Chairperson of the Buket Linteung Village Disaster Risk Reduction Forum, Langkahan District). The simulation can be said as a way of presenting learning experiences by using artificial situations to understand certain concepts, principles, or skills (Abidin et al., 2014). Disaster simulations are considered to be able to increase community preparedness because through these simulations the community can experience a crisis before it occurs. Community preparedness appears in response to disasters because people already know disasters so they can plan actions that need to be done when a disaster occurs.

According to researchers, the local government under the authority of the Regional Disaster Management Agency provides education to the public about the dangers of natural disasters through socialization in the form of face-to-face communication. Likewise in disaster simulation activities carried out regularly to provide personal habituation as well as to test community alertness. Interpersonal communication and face-to-face communication in the implementation of effective socialization and simulation to change community knowledge about the condition of the area in North Aceh that is prone to disasters. As well as being effective in changing people's attitudes to be more responsive when signs of disaster are seen.

BPBD also uses organizational communication in the form of coordination with local government, SAR, Disaster Risk Reduction Forum in the Village, Disaster Alertness Health Office, PMI, and other related parties.
The results of the coordination become the basis for planning in preventing and managing disasters. Organizational communication is effective in increasing cross-sectoral cooperation. Good cooperation between related parties can accelerate disaster management appropriately. According to organizational information theory from Karl Weick discusses the dissemination of information within an organization, so that the organization can be sustained (West \& Turner, 2017). Behavior in organizations is said to be mutually orderly if a person's behavior in the organization depends on the behavior of others (Pace \& Faules, 2013). The main concern of Organizational Information Theory is organizing information that has an important role in the success of an organization. The hardest part of the information processing task in an organization is interpreting and transmitting the information obtained (Morissan, 2014).

Organizational information theory has assumptions, namely: 1) organizational goals can be achieved if the information system is functioning effectively; 2) the organization receives different information in its obscurity. The ambiguity referred to here is the ambiguity of information received by the organization; 3 ) to reduce the obscurity of information involving humans in the organization. So, for that, the organization cooperates so that it can reduce ambiguity and the information received can be understood properly (West \& Turner, 2017). Besides, BPBD uses effective mass communication to convey information to a wide and heterogeneous community. Efforts to minimize the possibility of natural disasters are also carried out through physical development. Because almost part of the sub-district in North Aceh Regency is prone to landslides and floods that often occur every year. The North Aceh Regency Government since 2013 has planned the construction of the Keureutoe reservoir in the Payabakong Hinterland to stem the flow of the Keureutoe river water. Since the construction of the Keureutoe reservoir, flooding conditions in some flood-prone villages have begun to diminish. Construction of the reservoir is ongoing and is expected to be completed in 2022 (interview with Fauzi Yusuf, Deputy Regent of North Aceh).

\section{Communication Media in The Delivery of Disaster Information}

It is a necessity if the media plays a role in the dissemination of information about the disaster that occurred. Implementation of functions communication 
itself rests on the capabilities of the media and employees provide the information needed and considered important by the public (Prajarto, 2008). Regional Disaster Management Agency in North Aceh Regency in delivering disaster information is carried out through various media, namely:

The mass media, using local print media and online media such as the Serambi Indonesia daily in informing BPBD policies on disasters. Also informs disasterprone areas and BPBD's handling of disaster victims (interview with Amir Hamzah, Head of North Aceh BPBD). Electronic mass media that is using national radio in regions such as RRI. Collaborating in informing the use of local wisdom in disaster management, namely the RRI kentongan program for disaster response which was carried out launching at the Buket Linteung Village, Langkahan District. This area is one area that is prone to flooding and landslides until there was a flood that was quite severe, namely water reaching the shoulder length of adults. With this disaster kentongan program, it can provide education about the understanding of disasters to the community, so that the community is responsive and resilient in dealing with disasters (interview with Muhtar, Chairperson of the Buket Linteung Village Disaster Risk Reduction Forum, Kecamatan Langkahan). RRI's disaster response program is a national program launched by RRI to educate and provide information to the public following RRI's main tasks and functions, namely to provide intelligent and educational information to the public including disaster education (interview with Agung Prasetya, RRI head Lhokseumawe).

Social media, such as WhatsApp, Facebook, and Instagram because social media is now a medium that is very fast and easily accessible to all levels of society. Social media also makes patterns of interpersonal communication more personal and involve the wider community. Through social media information can be disseminated about the early signs of a disaster, what to do in the event of a disaster, evacuation routes, and first aid when a disaster occurs. (interview with Amir Hamzah, Head of North Aceh BPBD). Social media is also used as a medium of coordination between the Village Head and the Camat and the North Aceh BPBD in disaster prevention and management efforts. Like mobile phones, all village heads are always active, so it is easy to coordinate with the sub-district head if a disaster occurs in the village and the sub-district head is quick to report to BPBD (interview with Kausar, sub- district head). According to the author, the North Aceh BPBD in conveying information related to disaster mitigation uses media communications, including social media because the use of social media today with the development of communication technology becomes important in maximizing disaster emergency response and disaster recovery activities. Besides, the use of social media also makes it easier for BPBD to map or find out the exact location of a disaster. The use of social media streamlines information flow so that the flow of information related to disaster mitigation creates synchronization of policies between local government and sub-district and village governments.

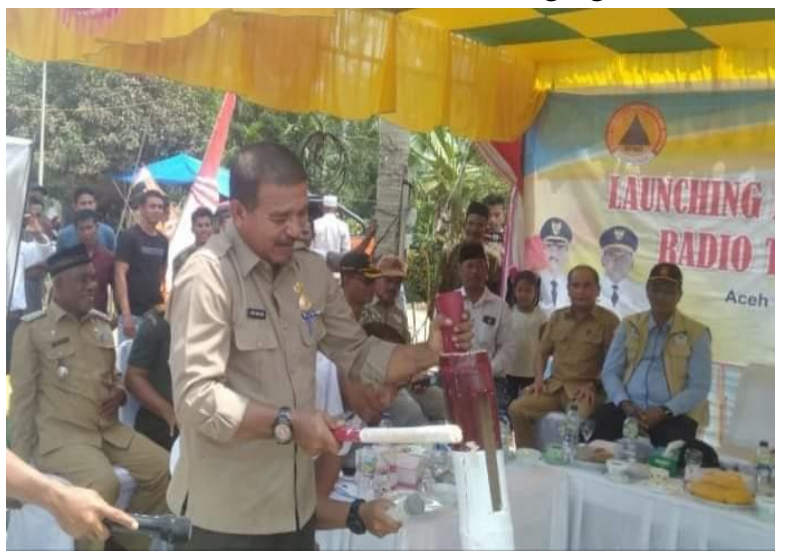

Figure 2 The Use of Kentongan as Disaster Mitigation Media

Traditional media, such as through Friday sermons, because religious approaches would be more appropriate in conveying disaster mitigation information. Also, use kentongan as a form of preserving local wisdom. Because, traditional communication media live among the community itself, sourced from the culture of the local community, and become a means of interaction. For this reason, it is necessary to pass down behavioral values and moral values using the media to the next generation. Traditional media supports modern media in their use as educational media in the event of a disaster. The use of traditional media is very effective when all communication tools that use technology do not function in the event of a disaster. This traditional media is a reliable source of information besides modern communication technologies such as the early warning system technology that has been installed (interview with Hasbullah, North Aceh SAR Head).

\section{CONCLUSION}

This study has analyzed the communication patterns used by the North Aceh BPBD in improving community alertness with interpersonal 
communication patterns carried out in verbal and nonverbal forms. Besides, face-to-face communication between BPBD and the community through socialization, training, and simulation. Also organizational communication between the BPBD and related institutions namely the Regent, head of the district, SAR Team, Disaster Risk Reduction Forum, PMI, and other related institutions. North Aceh BPBD also uses mass communication, namely the delivery of information through mass media simultaneously at the same time to a large and heterogeneous community. Meanwhile, the media used by BPBD in improving community alertness in North Aceh Regency are print media such as Serambi Indonesia daily in the form of news, online media, radio media such as RRI in the form of news programs, talk shows, and kentongan programs, social media, namely Facebook, Instagram, WhatsApp, and traditional media, namely kentongan.

\section{ACKNOWLEDGMENTS}

The authors expressed a high appreciation for the Regional Government of North Aceh Regency, the North Aceh District Disaster Management Agency, the Head of Langkahan District, the Chairperson of the North Aceh SAR, the Chair of the Gampong Buket Linteung Disaster Risk Reduction Forum, Langkahan District, Head of RRI Lhokseumawe and the community for their support of this research.

\section{REFERENCES}

Abidin, A. Z., Sunarhadi, A. M., \& Nanda, K. (2014). Peran Pemerintah Desa dan Kesiapsiagaan Masyarakat dalam Menghadapi Bencana Kekeringan di Desa Lorog Kecamatan Tawangsari Kabupaten Sukoharjo. Pertemuan Ilmiah Tahunan XVII Dan Kongres Ikatan Geografi Indonesia-Potensi Geografi Indonesia Menuju Abad 21 Asia.

Arisandi, F. K., \& Umam, C. (2019). KOMUNIKASI BENCANA SEBAGAI SEBUAH SISTEM PENANGANAN BENCANA DI INDONESIA. Mediakom, 3(1), 25-37. https://doi.org/http://dx.doi.org/10.35760/mkm.2019 .v3i1.1980

Bakornas PB. (2007). Pengenalan Karakteristik Bencana dan Upaya Mitigasinya di Indonesia (2nd ed.). Direktorat Mitigasi Lakhar Bakornas PB.

Cangara, H. (2015). Pengantar Ilmu Komunikasi. PT Raja Grafindo Persada.

Carter, W. N. (2008). Disaster Management: a Disaster Manager's Handbook. Asian Development Bank. https://doi.org/www.adb.org

Coppola, D. P., \& Maloney, E. K. (2009). Emergency Alertness Strategies for Creating a Disaster Resilient
Public (1st ed.). Taylor and Francis Group, LLC. https://doi.org/https://doi.org/10.4324/97803678028 20

Effendy, O. U. (2017). Ilmu Komunikasi Teori Dan Praktek. PT. Remaja Rosdakarya.

Emosda, L., \& Fadzlul. (2014). Mengkonstruk Pemahaman Masyarakat Peduli Bencana Alam Banjir. Jurnal Pengabdian Masyarakat, 29(3), 21-29.

Febriana, Sugiyanto, D., \& Abubakar., Y. (2015). Kesiapsiagaan Masyarakat Desa Siaga Bencana dalam Menghadapi Bencana gempa Bumi di Kecamatan Meuraxa Kota banda Aceh. Jurnal Ilmu Kebencana Pascasarjana Unsyiah, 2(3), 41-49.

Haddow, K. S., \& Haddow, G. D. (2014). Disaster Communications in a Changing Media World (2nd ed.). Elsevier.

Lestari, P., Kusumayudha, S. B., Paripurno, E. T., \& Ramadhaniyanto, B. (2016). Komunikasi Lingkungan untuk Mitigasi Bencana Erupsi Gunung Sinabung. Jurnal ASPIKOM, 3(1), 56-64. https://doi.org/10.24329/aspikom.v3i1.98

Liliweri, A. (2015). Komunikasi antarpersonal. Prenadamedia Group.

Littlejohn, S. W., \& Foss, K. A. (2014). Teori Komunikasi. Salemba Humanika.

Maarif, S. et al. (2012). Kontestasi Pengetahuan dan Pemaknaan tentang Ancaman Bencana Alam (Studi Kasus Ancaman Bencana Gunung Merapi). Jurnal Penanggulangan Bencana, 3(1), 1-13.

Morissan. (2014). Teori Komunikasi Individu Hingga Massa. Kencana Prenadamedia Group.

Nasution, S. (2012). Metode Research (Penelitian Ilmiah). Bumi Aksara.

Pace, R. W., \& Faules, D. F. (2013). Komunikasi Organisasi: Strategi Meningkatkan Kinerja Perusahaan (Dedy Mulyana (ed.)). Remaja Rosdakarya.

Pahleviannur, M. R. (2019). Edukasi Sadar Bencana Melalui Sosialisasi Kebencanaan Sebagai Upaya Peningkatan Pengetahuan Siswa Terhadap Mitigasi Bencana. Jurnal Pendidikan Ilmu Sosial, 29(1), 49-55. https://doi.org/10.23917/jpis.v29i1.8255

Prajarto, N. (2008). Bencana, Informasi dan Keterlibatan Media. Jurnal Ilmu Sosial Dan Ilmu Politik, 11(3), 124. https://doi.org/https://doi.org/10.22146/jsp.10989

Rahayu, P. B., Asrul, L., \& Akbar, M. (2014). Peran Media Cetak Lokal dalam Mitigasi Bencana Banjir Terhadap Kesadaran Masyarakat di Kota Makassar. Jurnal Kareba, 3(1), 68-76. https://doi.org/http://dx.doi.org/10.31947/kjik.v3i1.5 72

Rudianto. (2015). Komunikasi dalam Penanggulangan Bencana. Jurnal Simbolika, 1(1), 51-61. https://doi.org/https://dx.doi.org/10.31289/simbollik a.v1i1.49

Seneviratne, K. (2010). Disaster Knowledge Factors in Managing Disasters Successfully. International Journal of Strategic Property Management, 14(10), 376-390.

https://doi.org/https://doi.org/10.3846/ijspm.2010.28

Shaw, R., Srinivas, H., \& Sharma, A. (2009). Urban Risk Reduction: An Asian Perspective,. Emerald Group Publishing Limited. 
Suhardjo, D. (2011). Arti Penting Pendidikan Mitigasi Bencana dalam Mengurangi Resiko Bencana. Cakrawala Pendidikan Jurnal Ilmiah Pendidikan, 2(Th.XXX Edisi Khusus Dies Natalis UNY), 174188.

https://doi.org/https://doi.org/10.21831/cp.v0i2.4226

Sutton, J., \& Tierney, K. (2006). Disaster Preparedness : Concepts, Guidance, and Research. Report Prepared for the Fritz Institute Assessing Disaster Preparedness Conference Sebastopol, 1-41.
UNESCO - LIPI. (2008). Kajian Kesiapsiagaan Masyarakat dalam Menghadapi Ancaman Bencana Alam.

West, R., \& Turner, L. H. (2017). Pengantar Teori Komunikasi: Analisis dan Aplikasi (5th ed.). Salemba Humanika.

Widjaja. H.A.W. (2010). Komunikasi: Komunikasi dan Hubungan Masyarakat. Bumi Aksara. 
Halaman ini sengaja dikosongkan 